\title{
BULK COMPONENTS IN LUNAR ROCKS
}

\author{
JOUKO RAITALA
}

RAITALA, J. 1980: Bulk components in lunar rocks. Bull. Geol. Soc. Finland 52-2, 165-174.

The deviations of principal lunar rock oxides collected from periodicals are presented in the form of frequency distribution graphs. The geochemical characteristics of rock types from different landing sites are briefly discussed.

Of the major lunar rock components $\mathrm{Al}_{2} \mathrm{O}_{3}, \mathrm{FeO}, \mathrm{CaO}$ and $\mathrm{MnO}$ are most indicative of terra-mare contrary. Terra rock classification is not unambiguous but mare basalts can be divided into highand low-titanium basalts with several subgroups.

Since lunar missions are few in number and are directed at restricted areas there are evidently still many unsampled lunar rock types.

J. Raitala, Aarne Karjalainen Observatory, University of Oulu, Torikatu 7, SF-90100 Oulu 10, Finland.

\section{Introduction}

Apart from the Earth the Moon is the only terrestrial planet from which samples have been returned. It has become clear that lunar sample studies carry much information about early planetary geological processes. It may thus be highly important for all who are interested in Earth and planetary sciences to have some essential chemical knowledge of lunar rock characteristics.

Publication of the chemical aspects of the lunar samples has been intensive but also widely dispersed among periodicals, so that it is very difficult to find an overview of essential lunar rock bulk chemistry. The available analytical data does, however, permit a statistically comprehensive survey of lunar rock compositions, ranges of variation and distributions of individual principal oxides. It is also the purpose of the present study to describe some typical compositional characteristics of lunar rocks at different locations.

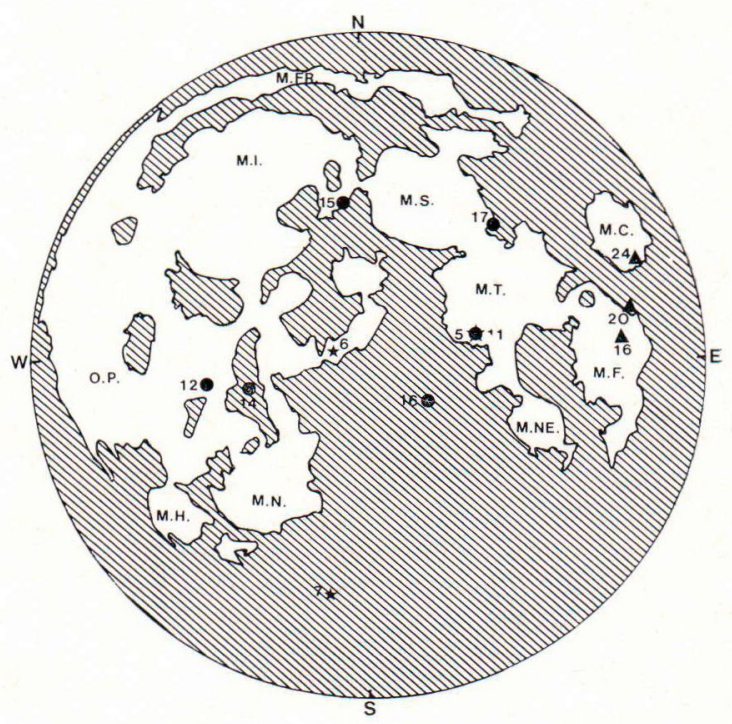

Fig. 1. Sketch of Apollo (•), Luna (A) and Surveyor ( $\star$ ) landing sites on the Moon's near side. Terra areas are shown lined. M.C. = Mare Crisium, M.F. = Mare Fecunditatis, M.FR. = Mare Frigoris, M.H. = Mare Humorum, M.I. = Mare Imbrium, M.NE. = Mare Nectaris, M.N. = Mare Nubium, M.S. = Mare Serenitatis, M.T. = Mare Tranquillitatis, and O.P. = Oceanus Procellarum. 

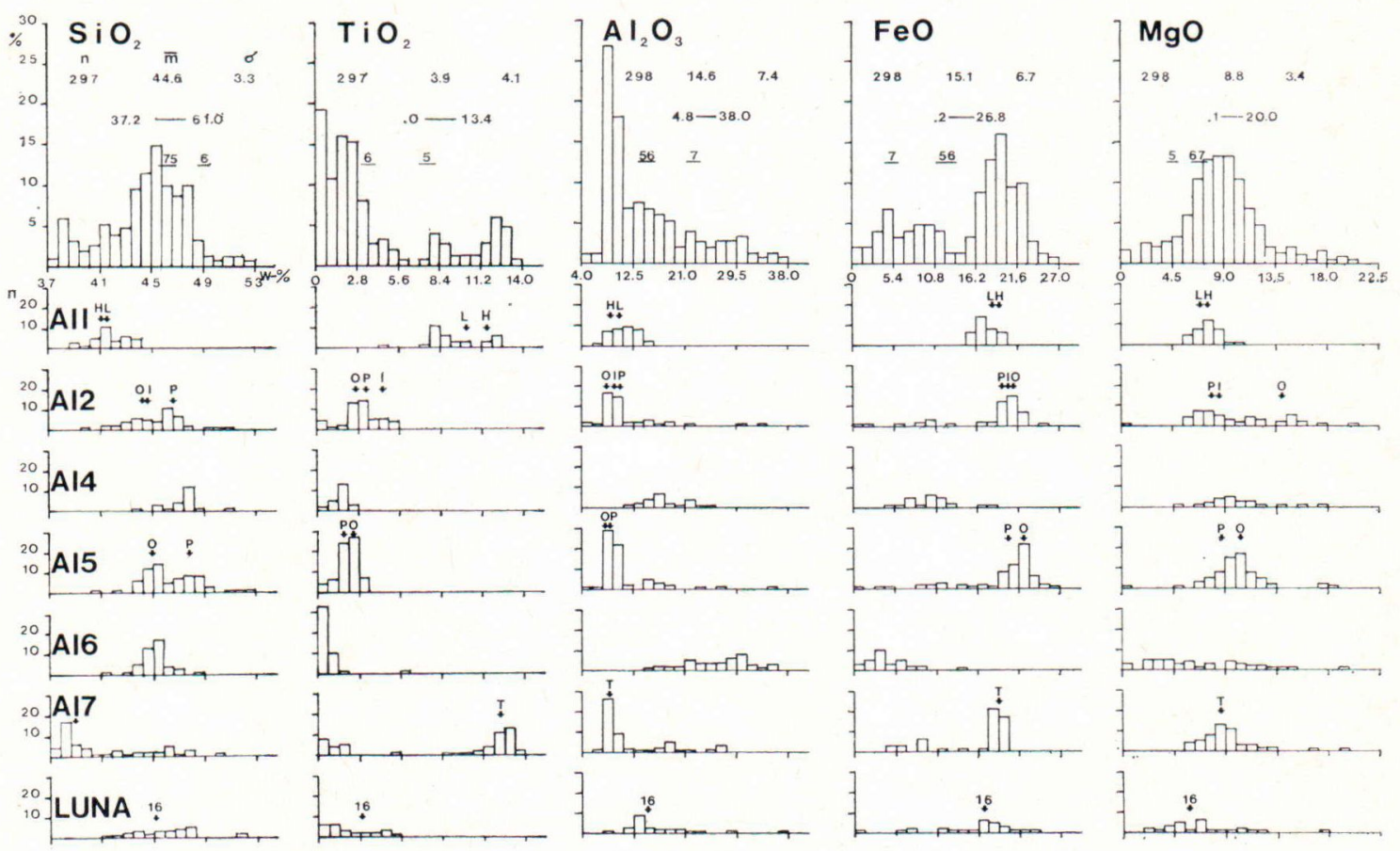

Data for rock and soil chemistry is available from three locations analysed automatically during the Surveyor program, from six landing locations sampled during the Apollo program, and from three automatically sampled Luna locations (Fig. 1). A total of some 380 kilogrammes of returned samples represents the topmost surface regolith of a clearly mixed nature and thus apart from some kind of soil averages of the surface around sampling locations also comprises rock fragments, boulders and glass spherules which may originate from even distant unsampled regions with different rock types.

\section{Method of study}

The lunar rock analytioal data from twelve locations on the Moon was extracted from the literature. The objective was to obtain chemical characteristics of local or even areal lunar surface rocks and indirect implications of the bulk composition of lunar crust and mantle.

The main sources of the chemical analyses of the lunar rocks discussed here were the eight Supplements of the Geochimica et Cosmochimica Acta (see Appendix). Further selenochemical data was also collected by searching important periodicals and books, as can be seen from the detailed source list in the Appendix. The most important data source for Apollo 11 samples was the Apollo11 Lunar Sample Information Catalogue compiled by Kramer et al. (1977).

The collected data was stored and statistically treated using the Univac 1100/20 computer system of the University of Oulu and the HARDROCK petrographic calculation package by Roger Till (1977). The program was used in this work only to perform statistical parameters and histograms for every bulk oxide. 

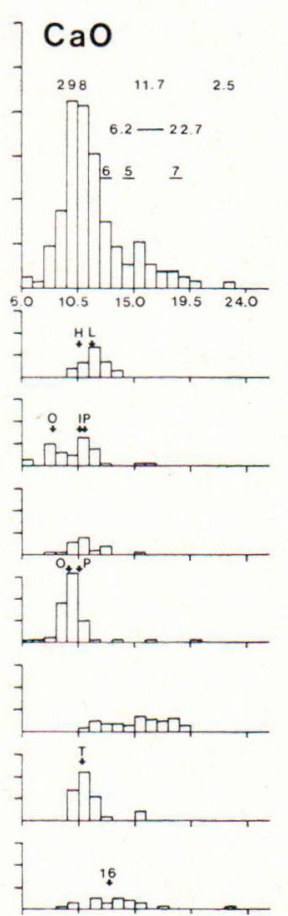
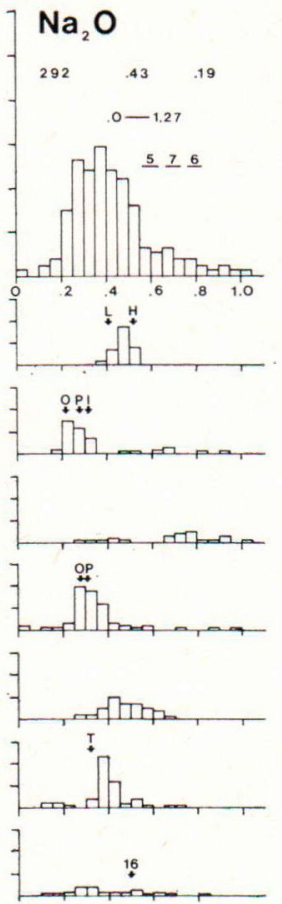
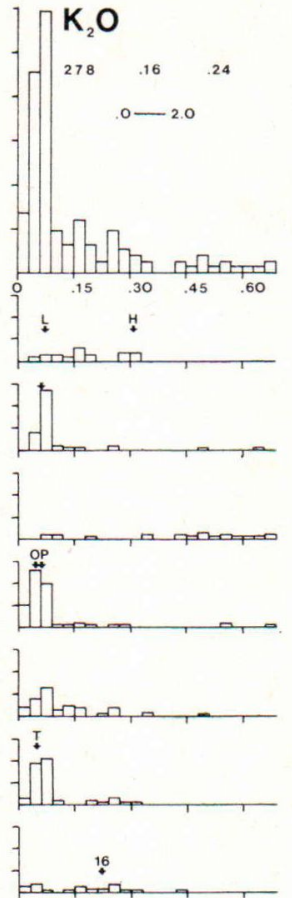
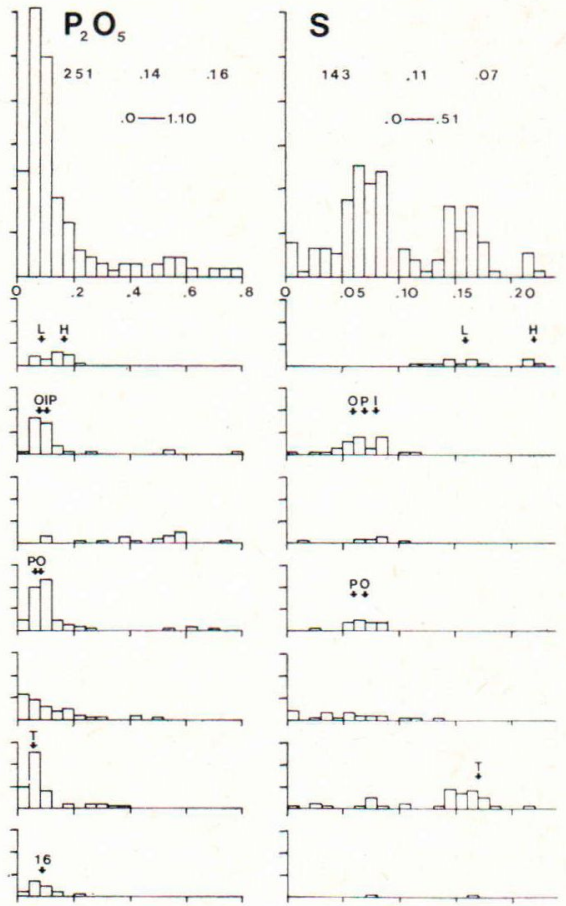

Fig. 2. Frequency distribution graphs of principal oxides of lunar rocks. The graph of FeO indicates the total iron distribution. For an explanation of scales and indicated values and symbols see the graph of $\mathrm{SiO}_{2}, \mathrm{n}=$ number of analysis, $\overline{\mathrm{m}}=$ the mean value, $\sigma=$ the standard deviation, and $\mathrm{w}-\%=$ oxide weight percentage. Small arrows in areal graphs indicate mean values of certain basaltic rocks. The mean values of oxide percentages from Surveyor 5, 6 and 7 sites are indicated in the total graphs. For further explanations see the text.

\section{Presentation of data}

\section{Major oxide frequency distributions}

Fig. 2 sets out the frequency distributions of essential weight percent variation range parts for principal oxides $\left(\mathrm{SiO}_{2}, \mathrm{TiO}_{2}, \mathrm{Al}_{2} \mathrm{O}_{3}\right.$, $\mathrm{FeO}, \mathrm{MgO}, \mathrm{CaO}, \mathrm{Na}_{2} \mathrm{O}, \mathrm{K}_{2} \mathrm{O}, \mathrm{P}_{2} \mathrm{O}_{5}, \mathrm{ZrO}_{2}, \mathrm{MnO}$, and $\mathrm{Cr}_{2} \mathrm{O}_{3}$ ) and sulphur (S).

Histograms representing the total distribution of each oxide in lunar rocks can be divided into three groups. $\mathrm{MgO}, \mathrm{CaO}, \mathrm{Na}_{2} \mathrm{O}$ and $\mathrm{Cr}_{2} \mathrm{O}_{3}$ seem to have quite symmetrical

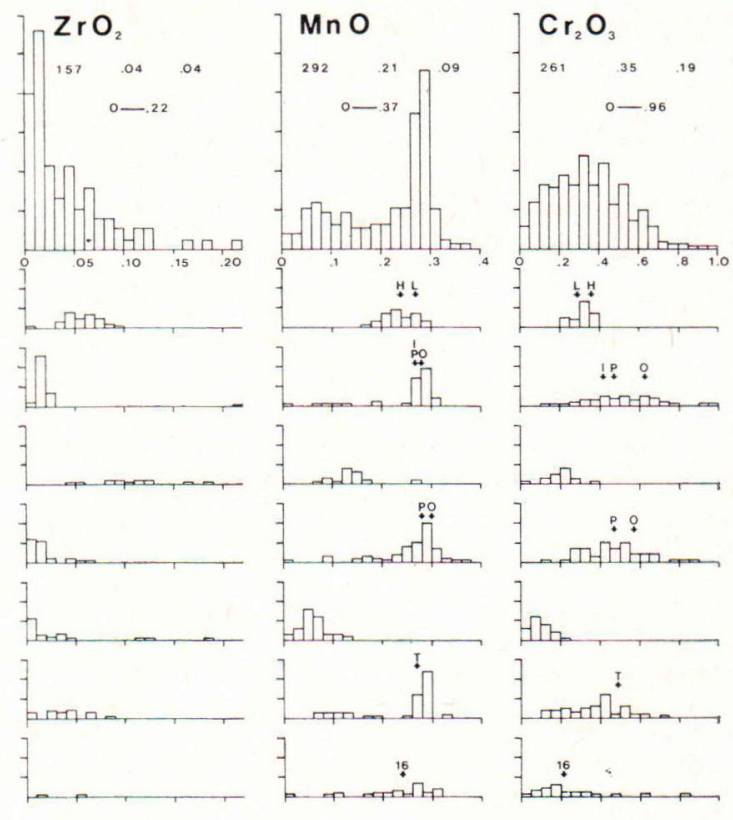

distributions around the mean values. In the total graphs of $\mathrm{SiO}_{2}, \mathrm{TiO}_{2}, \mathrm{FeO}, \mathrm{S}$ and $\mathrm{MnO}$ there are clear bi- or even multipartite fea- 
tures. The rest of the distribution graphs $\left(\mathrm{Al}_{2} \mathrm{O}_{3}, \mathrm{~K}_{2} \mathrm{O}, \mathrm{P}_{2} \mathrm{O}_{5}\right.$ and $\left.\mathrm{ZrO}_{2}\right)$ are all very steep with one very high peak and adjoining multipartite and diminishing distribution tail.

The shape of each total distribution histogram depends very much on areally defined sampled subgroups. In the case of considerably symmetrical distribution graphs there are either quite similar mean values within each area or areal differences in distribution are reduced by a favourable superposition. The leptokurtosis of the diagram may show that the material consists of two or more populations with the same mean values but with different variances. The platykurtosis of the diagram may indicate the existence of two or more populations with similar variances but with different mean values. Multipartite, slanting and asymmetrical graphs as also graphs with a large variation range indicate that there are several rock groups either with unequal occurrence on the lunar surface or, which is likely, with unequal sampling.

Since there is no water or atmosphere on the Moon nearly all ordinary hydrous terrestrial minerals are absent. Highly calcic plagioclases, pyroxenes (one of them, named pyroxferroite forms a continuous sequence of intermediate compositions between hedenbergite and ferrosilite), and olivines are all main rock-forming mineral groups on the Moon. Titanium-rich rocks may have up to 20 per cent ilmenite. Armalcolite (Fe, $\mathrm{Mg}$ ) $\mathrm{Ti}_{2} \mathrm{O}_{5}$ is a new mineral, as is also a complicated iron, titanium, and zirconium silicate named tranquillityite. High temperature $\mathrm{SiO}_{2}$ polymorphs, tridymite and cristobalite, occur in very small accounts but they are more common than quartz. Metallic iron is a widespread accessory mineral on the Moon, being partly of meteoritic origin. Some troilite is found in association with the native iròn (Frondel, 1975).

The composition of a typical sampled lunar rock might be thought to be indicated in terms of mean values of oxide weight percentages, as indicated in Table 1 . This is, however, a risky simplification and to achieve a better understanding of the lunar chemistry we must examine main sampled locations individually.

\section{Selenochemistry area by area}

When the lunar geochemistry of the Apollo landing sites are examined closely differences between them are readily found. There are also different kinds of rocks within each particular area. Some typical bulk chemical

Table 1. Statistical parameters of major lunar rock oxides.

\begin{tabular}{|c|c|c|c|c|}
\hline Component & $\begin{array}{l}\text { Mean oxide } \\
\text { weight } \% \text { of } \\
\text { lunar rocks }\end{array}$ & $\begin{array}{l}\text { Standard } \\
\text { deviation }\end{array}$ & $\begin{array}{l}\text { Range of } \\
\text { variation }\end{array}$ & $\begin{array}{c}\text { Number of } \\
\text { analyses }\end{array}$ \\
\hline $\mathrm{SiO}_{2}$ & 44.64 & 3.28 & $37.19-61.00$ & 297 \\
\hline $\mathrm{TiO}_{2}$ & $\begin{array}{r}11.07 \\
3.97\end{array}$ & 4.10 & $.01-13.45$ & 297 \\
\hline $\mathrm{Al}_{2} \mathrm{O}_{3}$ & 14.60 & 7.36 & $4.81-38.00$ & 298 \\
\hline $\mathrm{FeO}$ & 15.09 & 6.67 & $.18-26.75$ & 298 \\
\hline $\mathrm{MgO}$ & 8.79 & 3.35 & $.09-19.97$ & 298 \\
\hline $\mathrm{CaO}$ & 11.69 & 2.54 & $6.20-22.70$ & 208 \\
\hline $\mathrm{Na}+\mathrm{O}$ & .43 & .19 & $.01-1.27$ & 292 \\
\hline $\mathrm{K}_{2} \mathrm{O}$ & .16 & .24 & $.01-2.00$ & 278 \\
\hline $\mathrm{P}_{2} \mathrm{O}_{5}$ & .14 & .16 & $.00-1.10$ & 251 \\
\hline $\mathrm{S}$ & .11 & .07 & $.00-\quad .51$ & 143 \\
\hline $\mathrm{MnO}$ & .21 & .09 & $.00-.37$ & 292 \\
\hline $\mathrm{Cr}{ }_{2} \mathrm{O}$ & .35 & .19 & $.00-.96$ & 261 \\
\hline $\mathrm{ZrO}_{2}$ & .04 & .04 & $.00-\quad .22$ & 157 \\
\hline
\end{tabular}


Table 2. Major chemistry of lunar basalt types (Papike et al., 1976).

\begin{tabular}{|c|c|c|c|c|c|c|c|c|}
\hline & \multicolumn{2}{|c|}{ Apollo 11 basalts } & \multirow{2}{*}{$\begin{array}{c}\text { Apollo } 17 \\
\text { basalts }\end{array}$} & \multicolumn{2}{|c|}{ Apollo 15 basalts } & \multicolumn{3}{|c|}{ Apollo 12 basalts } \\
\hline & low $\mathrm{K}$ & high $\mathrm{K}$ & & olivine & pigeonite & olivine & pigeonite & ilmenite \\
\hline $\mathrm{SiO}_{2}$ & 40.67 & 40.37 & 38.84 & 44.98 & 47.98 & 44.32 & 46.46 & 44.47 \\
\hline $\mathrm{TiO}_{2}$ & 10.18 & 11.77 & 12.35 & 2.41 & 1.82 & 2.65 & 3.35 & 4.63 \\
\hline $\mathrm{Al}_{2} \mathrm{O}_{3}$ & 10.40 & 8.84 & 8.84 & 8.80 & 9.46 & 8.03 & 10.38 & 9.76 \\
\hline $\mathrm{FeO}$ & 18.68 & 19.28 & 18.94 & 22.37 & 20.13 & 21.11 & 19.72 & 20.78 \\
\hline $\mathrm{MnO}$ & .27 & .24 & .27 & .30 & .28 & .28 & .27 & .27 \\
\hline $\mathrm{MgO}$ & 6.92 & 7.56 & 8.52 & 10.42 & 8.74 & 14.07 & 7.94 & 8.52 \\
\hline $\mathrm{CaO}$ & 11.70 & 10.59 & 10.80 & 9.79 & 10.54 & 8.61 & 11.03 & 10.78 \\
\hline $\mathrm{Na}_{2} \mathrm{O}$ & .41 & .52 & .32 & .28 & .31 & .22 & .28 & .32 \\
\hline $\mathrm{K}_{2} \mathrm{O}$ & .07 & .31 & .05 & .05 & .06 & .06 & .07 & .07 \\
\hline $\mathrm{P}_{2} \mathrm{O}_{5}$ & .09 & .17 & .06 & .08 & .07 & .08 & .11 & .10 \\
\hline $\mathrm{S}$ & .16 & .22 & .17 & .07 & .06 & .06 & .07 & .08 \\
\hline $\mathrm{Cr}_{2} \mathrm{O}_{3}$ & .29 & .36 & .49 & .57 & .47 & .63 & .47 & .42 \\
\hline
\end{tabular}

characteristics of main rock types are discussed on the basis of areal frequency distribution graphs in Fig. 2. Attention should also to be paid to different lunar basalt types and rocks indicated in Tables 2 and 3 .

Rocks returned from the Moon by Apollo and Luna mission and automatically analysed at Surveyor 5, 6 and 7 sites can be divided into two main groups, with a clear disparity in bulk chemistry. These terra and mare rocks can be further divided into several chemically and petrologically determined subgroups with unequal crystallization and brecciation history. Highly brecciated terra rocks have a very derivative nature with only few original textural features. Mare rocks are not so complicated and represent several basaltic igneous rock types. Terra rocks are all strongly brecciated and mixtures of even several older mineral, rock and breccia fragments and glasses and thus constitute some kind of averages. All the rocks are, however, treated and presented here together. The reason for this is that terra rocks can be regarded as representing the only obtainable source of the oldest phases of early lunar de-

Table 3. Major components of some lunar rocks.

\begin{tabular}{|c|c|c|c|c|c|c|c|c|}
\hline $\begin{array}{l}\text { Compo- } \\
\text { nent }\end{array}$ & $\begin{array}{l}12013 \\
\text { granitic } \\
\text { rock }\end{array}$ & $\begin{array}{l}\text { Apollo } 12 \\
\text { anortho- } \\
\text { sitic } \\
\text { gabbro } \\
\text { fragment }\end{array}$ & $\begin{array}{c}\text { Apollo } 12 \\
\text { anortho- } \\
\text { sitic } \\
\text { norite } \\
\text { fragment }\end{array}$ & $\begin{array}{c}12037 \\
\text { alcalic } \\
\text { high- } \\
\text { Al basalt }\end{array}$ & $\begin{array}{c}14065 \\
\text { breccia } \\
\text { rock }\end{array}$ & $\begin{array}{c}15015 \\
\text { breccia } \\
\text { rock }\end{array}$ & $\begin{array}{c}61295 \\
\text { breccia } \\
\text { matrix }\end{array}$ & $\begin{array}{l}76015 \\
\text { noritic } \\
\text { breccia }\end{array}$ \\
\hline $\mathrm{SiO}_{2}$ & 61.00 & 45.00 & 51.10 & 50.10 & 48.00 & 47.11 & 45.19 & 46.40 \\
\hline $\mathrm{TiO}_{2}$ & 1.20 & .40 & .40 & .68 & .95 & 1.90 & .56 & 1.53 \\
\hline $\mathrm{Al}_{2} \mathrm{O}_{3}$ & 12.00 & 30.20 & 17.30 & 22.40 & 21.00 & 14.46 & 28.29 & 17.70 \\
\hline $\mathrm{Cr}_{2} \mathrm{O}_{3}$ & .15 & .10 & .20 & & .10 & .40 & .06 & .19 \\
\hline $\mathrm{FeO}$ & 10.00 & 2.40 & 8.30 & 6.10 & 6.80 & 14.38 & 4.52 & 9.41 \\
\hline $\mathrm{MnO}$ & .12 & .00 & .10 & .06 & .12 & .19 & .06 & .13 \\
\hline $\mathrm{MgO}$ & 6.00 & 6.40 & 8.90 & 6.30 & 8.30 & 9.93 & 4.72 & 12.60 \\
\hline $\mathrm{CaO}$ & 6.30 & 15.30 & 10.00 & 12.60 & 12.00 & 10.47 & 16.16 & 11.00 \\
\hline $\mathrm{Na}_{2} \mathrm{O}$ & .69 & .60 & .90 & 1.27 & .92 & .31 & .45 & .72 \\
\hline $\mathrm{K}_{2} \mathrm{O}$ & 2.00 & .10 & 2.00 & 1.16 & 1.00 & .28 & .09 & .27 \\
\hline
\end{tabular}

Data sources:

12013 LSPET (1970), A 12 anorthositic gabbro and norite fragments Marvin et al. (1971), 12 037 Kurat et al. (1974), 14065 LSPET (1971), 15015 Scoon (1977), 61295 LSPET (1977), and 76015 Delano (1977). 
velopment and of proposed lunar differentiation.

A comparison of both the mean value and the standard deviation with the essential variation range of every graph indicates most easily the terra-mare contrary. Compositional differences between samples from rough and light terra highlands and relatively flat and dark mare lowlands are best seen in the wide range of variation and in the bipartity of the frequency distribution diagrams of $\mathrm{Al}_{2} \mathrm{O}_{3}, \mathrm{FeO}$ and $\mathrm{CaO}$.

The Apollo 16 landing site in the southern lunar highlands in the Descartes area was the only pure terra landing site during the Apollo program. Almost all of the 45 rocks from the Apollo 16 area discussed were evidently brecciated during the intense highland impact cratering. These terra rocks are richer in $\mathrm{Al}_{2} \mathrm{O}_{3}$ and $\mathrm{CaO}$ and poorer in $\mathrm{FeO}, \mathrm{MnO}$ and $\mathrm{Cr}_{2} \mathrm{O}_{3}$ when compared with other lunar rocks. The main terra rock mineral is anorthitic plagioclase. Terra rock composition ranges over a large aluminium weight percent variation from nearly pure aluminium rich anorthosites $\left(\sim 35\right.$ wt- $\left.\% \mathrm{Al}_{2} \mathrm{O}_{3}\right)$ via gabbroic anorthosites $\left(\sim 30\right.$ wt- $\left.\% \mathrm{Al}_{2} \mathrm{O}_{3}\right)$ and anorthositic gabbros $\left(\sim 26\right.$ wt- $\left.\% \mathrm{Al}_{2} \mathrm{O}_{3}\right)$ to troctolites $\left(\sim 23\right.$ wt- $\left.\% \quad \mathrm{Al}_{2} \mathrm{O}_{3}\right)$ and high-Al basalts (known also as low-K Fra Mauro basalts and having about $20 \mathrm{wt}-0 / \mathrm{Al}_{2} \mathrm{O}_{3}$ ). The classification of terra rocks is quite difficult because of their highly derivative nature (Taylor, 1975 , p. 215).

Most of the statistically presented 23 Apollo 14 samples from Fra Mauro formation are also breccias. Fra Mauro rocks, however, differ chemically from the other terra rocks in having remarkably high sodium, potassium, phosphorus and zirconium content in comparison with that of other lunar rocks (Fig. 2). Basaltic rocks of this kind are known by the acronym KREEP (K, Rare Earth Elements, P). Relatively high $\mathrm{Al}_{2} \mathrm{O}_{3}$ and low $\mathrm{FeO}, \mathrm{MnO}$ and $\mathrm{Cr}_{2} \mathrm{O}_{3}$ contents make these rocks resemble high-Al basalts from the Apollo 16 site. In addition to the higher $\mathrm{K}_{2} \mathrm{O}$ content compared with the Descartes terra rocks, there are also as the main classification basis of Fra Mauro rocks high abundances of some minor elements like $\mathrm{Ba}, \mathrm{U}, \mathrm{Th}$ and REE. The largest values of $\mathrm{K}_{2} \mathrm{O}$ and $\mathrm{S}$ rise to 1.00 and 0.51 weight percent respectively.

The classification of lunar mare basalts is more unambiguous than that of terra rocks and can be made by inspecting the mare basalt bulk chemistry. Because of the breccia samples from mare sites mean oxide values of different mare basalt types from Papike et al. (1976) are indicated in the graphs (Fig. 2) and in Table 2.

The most striking feature of almost all 35 of the Apollo 11 samples from the southern Mare Tranquillitatis is the enormous high $\mathrm{TiO}_{2}$ content. The existence of two Apollo 11 basalt groups is clearly seen in the distributions of potassium and sulphur. Arrows marked by $\mathrm{L}$ and $\mathrm{H}$ denote the mean values of low-potassium and high-potassium basalts respectively (Papike et al., 1976). These two groups also have slightly different other mean oxide percent values. These differences are, however, not so significant. The highest peak around the 8 weight percent in the Apollo $11 \mathrm{TiO}_{2}$ histogram is caused by breccias, a fact which reflects the presence of a low-titanium surface component. Sampled breccias are richer in $\mathrm{SiO}_{2}$ and $\mathrm{Al}_{2} \mathrm{O}_{3}$ and poorer in $\mathrm{FeO}$ than both the two $\mathrm{TiO}_{2}$-basalts.

Of 48 Apollo 12 rocks from Oceanus Procellarum about forty are classified as Apollo 12 olivine, pigeonite or ilmenite basalts (Papike et al., 1976). Olivine basalts have remarkably high $\mathrm{MgO}$ and $\mathrm{Cr}_{2} \mathrm{O}_{3}$ contents and low $\mathrm{SiO}_{2}$ and $\mathrm{CaO}$ contents when compared especially with pigenonite basalts from this area. The excess of $\mathrm{MgO}$ is explained by forsteritic olivine and $\mathrm{Cr}_{2} \mathrm{O}_{3}$ is shown to be hidden in such lunar olivines (Frondel, 1975, p. 264). A few Apollo 12 ilmenite basalts are 
slightly enriched in titanium as indicated already by the denoting mineral. There are also within the graphs some small samples rich in alkalis, phosphorus, silica and aluminium resembling the KREEP basalts and terra anorthosites. Some extreme $\mathrm{Na}_{2} \mathrm{O}, \mathrm{K}_{2} \mathrm{O}$ and $\mathrm{P}_{2} \mathrm{O}_{5}$ values rise to $1.27,2.00$ and 1.10 weight percent respectively. The enormously high lunar $\mathrm{SiO}_{2}$ value is that of 61.00 weight percent of sample 12013 .

The Apollo 15 site location at the Mare Imbrium edge is complicated by the adjacent high terra mountains and thus only a proportion of 68 samples have basaltic composition. Olivine and pigeonite basalts (Papike et al., 1976) from the Apollo 15 area resemble olivine and pigeonite basalts from the Apollo 12 site with only some small differences in chemical compositions. Apollo 15 pigeonite basalts are poorer in titanium and Apollo 15 olivine basalts are poorer in magnesium than otherwise analogous Apollo 12 basalts. The rest of the Apollo 15 samples are similar to the terra highland rocks collected from other landing sites. For the interpretation of the few low by-peaks in the Apollo 15 graphs compare them with the peaks in the Apollo 14 and Apollo 16 graphs.

The location of Apollo 17 landing site in the Taurus-Littrow valley is quite similar to the Apollo 15 area. Among the 53 Apollo 17 samples there are many kinds of lunar rocks. The major element variation of Apollo 17 basaltic samples (arrow marked by $\mathrm{T}$ in Fig. 2; Papike et al., 1976) resembles that of the Apollo 11 site. Apollo 17 titanium basalts are, however, more basic and for the most part slightly more $\mathrm{TiO}_{2}$-rich than Apollo 11 basalts. Their alkali content is nearly the same as that of the low-K Apollo 11 basalts. Terra rocks are seen in the Apollo 17 graphs as isolated distribution peaks or tails in about the same places as those of sampled terra areas.
For the sake of comparison a combination graph is also represented of the bulk chemistry of Luna 16, 20 and 24 rock fragments from Mare Fecunditatis, Apollonius terra region and Mare Crisium, respectively. The mean values of the oxide weight percentages of 16 Luna 16 rock fragments are marked by an arrow in the graph "LUNA» in Fig. 2. These basaltic rocks are slightly higher in $\mathrm{Al}_{2} \mathrm{O}_{3}, \mathrm{CaO}$ and $\mathrm{Na}_{2} \mathrm{O}$ relative to other mare basalts. The 4 Luna 20 rock pieces included are typical anorthositic terra samples. All 6 Luna 24 rock chips are so-called very low titanium basalts (Vaniman and Papike, 1977) with higher $\mathrm{SiO}_{2} \mathrm{FeO}, \mathrm{MgO}$ and lower $\mathrm{TiO}_{2}$, $\mathrm{Na}_{2} \mathrm{O}$ and $\mathrm{K}_{2} \mathrm{O}$ contents when compared with the indicated Luna 16 mean values.

Together with the total frequency distribution graphs the mean chemical compositions of the lunar surface at the Surveyor 5, 6 and 7 sites (Turkevich et al., 1969; Franzgrote et al., 1970; Patterson et al., 1970, respectively) are also indicated. From Surveyor data it can be seen that the Surveyor 7 site near the crater Tycho is composed of a typical terra-like material, while the Surveyor 5 and 6 sites represent mare-type sites. The Surveyor 5 landing area is essentially the same as that of the Apollo 11 mission. The mixedup nature of analysed Surveyor 5 samples, especially of soils, is best seen in the low titanium content compared with the Apollo 11 basalts.

\section{Additional remarks}

The representativeness of lunar sample analyses used in this paper requires some scrutiny. Because of the small size of sample chips analysed by the primary investigators there is a wide range of compositions indicated for single samples. The Apollo 11 Lunar Sample Information Catalogue by Kramer et al. (1977) gives controlled and 
averaged chemical data for the Apollo 11 samples. For many other samples several replicate analyses were found, that having the most average oxide percent values being chosen and completed for some missing oxides. The existence of some nonrepresentative individual analyses (for example some LSPET analyses) may cause some disorder, but this has been largely equalized in the graphs.

Statistical scatter and missaccent may be caused by different sample types unequal in size but similar in number. For example, all of the enclosed Luna samples are very small rock pieces. However, the enclosing of analyses of small sample chips, too, is important because not all lunar surface units have been sampled. The mixed-up nature of the overmost lunar surface means that even the tiniest fragments may indicate the existence of some distant rock types. The abundance and location of rock types found by examining the small size rock chips remains, however, unsolved. According to remote sensing studies by Pieters and McCord (1975) fourteen different mare basalt types were recognized by using the reflectance spectra. Only four of these major basalt types occur in the sampled regions.

For the completion of the sampled lunar rock type classification used in this paper attention should also be paid to age determinations, to minor element chemistry, to mineral assemblages and chemistry and, by inspecting the rock textures, to crystallization circumstances. The source regions and intrusion/extrusion conditions like the above individualized rock characteristics are discussed in numerous papers.

The terra-mare contrary is explained as indicating the early lunar differentiation phase. Plagioclase-rich terra material is thought to represent the floating and crustforming cumulate phase during the fractional crystallization of the first melting and cooling of the outermost lunar few hundred kilometres. Younger mare basalts were thus produced by later re-melting of downsettled olivine- and pyroxene-rich phases. In the reducing lunar environment the favoured divalent europium being similar in size and valency to $\mathrm{Sr}^{2+}$ can be hidden into feldspar lattices while the trivalent Eu with other trivalent rare earth elements will remain outside. During fractional crystallization the plagioclase-rich cumulate will also be enriched in Eu relative to the other REE. The negative europium anomaly in mare basalts and the positive Eu-anomaly in plagioclase rich terra rocks thus support the differentiation theory, as do some other trace element distribution characteristics (Taylor and Jakes, 1974). Contrasting anti-differentiation ideas are also represented (Wiik, 1975).

The existence of a meteoritic component in lunar samples is shown in numerous works. The continuous micrometeorite flux probably produced the $\mathrm{C} 1$ chondrite type siderophilevolatile excess which is found especially in mare soils. Highland soils show a high siderophile content compared with that of volatiles. This is explained as having been caused by the ancient basin-forming major impact bodies. At least six different impacting planetesimal varieties have been recognized. There are only some hints of the more recent crater-forming bodies (Morgan et al., 1977).

Acknowledgements - The author is indebted to Mrs. Nina Hekkala of the University of Oulu for typing the manuscript and to $\mathrm{Mr}$. R. Brown of the University of Oulu for checking the compiler's English. 


\section{References}

Franzgrote, E. J., Patterson, J. H., Turkevich, A. L., Economon, T. E. and Sowinski, K. P. (1970) Chemical composition of the lunar surface in Sinus Medii. Science 167: 376-379.

Frondel, J. W. (1975) Lunar Mineralogy. John Wiley \& Sons, New York.

Kramer, F. E., Twedell, D. B. and Walton, W. J. A., Jr. (1977) Apollo-11 Lunar Sample Information Catalogue, NASA JSC 12522, Houston, Texas.

Morgan, J. W., Ganapathy, R., Higuchi, H. and Anders, E. (1977) Meteoritic material on the Moon. Pp. 659-689 in The Soviet-American Conference on Cosmochemistry of the Moon and Planets, NASA SP-370, Washington, D.C.

Papike, J. J., Hodges, F. N., Bence, A. E., Cameron, M. and Rhodes, J. M. (1976) Mare basalts: Crystal chemistry, mineralogy, and petrology. Rev. Geophys. Space Phys. 14(4): 475-540.

Patterson, J. H., Turkevich, A. L., Franzgrote, E. J., Economon, T. E. and Sowinski, K. P. (1970) Chemical composition of the lunar surface in a terra region near the crater Tycho. Science 168: $825-828$.

\section{Appendix: Data sources}

The reference abbreviation PLSC $\mathrm{n}$ in the following list of data sources means Proceedings of the $n^{\text {th }}$ Lunar Science Conference, Geochim. Cosmochim. Acta Suppl. n.

Bence, A. E. et al. (1972) PLSC 3: 431-469. Compston, W. et al. (1971) PLSC 2: 1471-1485. Cuttitta, F. et al. (1971) PLSC 2: 1217-1229. Cuttitta, F. et al. (1973) PLSC 4: 1081-1096. Delano, J. W. (1977) PLSC 8: 2097-2123.

Dowty, E. et al. (1973) PLSC 4: 423-444.

Dowty, E. et al. (1974) PLSC 5: 431-445.

Dowty, E. et al. (1976) PLSC 7: 1833-1844.

Duncan, A. R. et al. (1973) PLSC 4: 1097-1113.

Duncan, A. R. et al. (1974) PLSC 5: 1147-1157.

Duncan, A. R. et al. (1976) PLSC 7: 1659-1671.

Eglinton, G. et al. (1974) PLSC 5: 1159-1180.

Grove, T. L. et al. (1977) PLSC 8: 1549-1579.

Haskin, L. A. et al. (1973) PLSC 4: 1275-1296.

Haskin, L. A. et al. (1974) PLSC 5: 1213-1225.

Hubbard, N. J. et al. (1972) Contribution 88, Lunar Science Institute Houston, Texas.

Hubbard, N. J. et al. (1972) PLSC 3: 1161-1179.
Pieters, C. and McCord, T. B. (1975) Classification and distribution of lunar mare basalt types. Pp. 125-129 in Papers Presented to the Conference on Origins of Mare Basalts and Their Implications for Lunar Evolution, Lunar Science Institute, Houston, Texas.

Taylor, S. R. (1975) Lunar Science: A Post-Apollo View. Pergamon Press Inc., New York.

- and Jakeš, P. (1974) The geochemical evolution of the Moon. Proc. 5th Lunar Sci. Conf. (2): $1287-1305$.

Till, R. (1977) The HARDROCK package, a series of FORTRAN IV computer programs for performing and plotting petrochemical calculations. Computers \& Geosciences 3: 185-243.

Turkevich, A. L., Franzgrote, E. J. and Patterson, J. H. (1969) Chemical composition of the lunar surface in Mare Tranquillitatis. Science 167: $277-279$.

Vaniman, D. T. and Papike, J. J. (1977) Very low Ti (VLT) basalts: A new mare rock type from the Apollo 17 drill core. Proc. 8th Lunar Sci. Conf. (2): 1443-1471.

Wiik, H. B. (1975) Viisi vuotta apollotutkimuksia. Tähtiaika 5: 4-15.

Hubbard, N. J. et al. (1973) PLSC 4: 1297-1312. Hubbard, N. J. et al. (1974) PLSC 5: 1227-1246. Irving, A. J. (1977) PLSC 8: 2433-2448.

Jarosewich, E. et al. (1977) Lunar Sample Studies, NASA SP-418. Washington, D.C.: 35-40.

Juan, V. C. et al. (1974) Lunar Science V. Houston, Texas: $394-396$.

Kramer, F. E. et al. (1977) Apollo 11 Lunar Sample Information Catalogue. Houston, Texas. Kurat, G. et al. (1974) Tschermaks Min. Petr. Mitt. 21: $179-195$.

Kurat, G. et al. (1977) Meteorites 6: 285-286.

Lindström, M. M. et al. (1977) PLSC 8: 2137-2151.

LSPET (1970) Science 167: 1325-1339.

LSPET (1971) Science 173: 681-693.

LSPET (1972) Science 175: 363-375.

LSPET (1973) Science 179: 23-34.

LSPET (1973) Science 182: 659-672.

Marvin, U. B. et al. (1971) PLSC 2: 679-699.

Mason, B. H. et al. (1972 PLSC 3: 785-796.

Mason, B. H. et al. (1977) Lunar Sample Studies, .NASA SP-418. Washington, D.C: $41-47$.

Meyer, C. et al. (1971) PLSC 2: 393-411.

Nava, D. F. (1974) PLSC 5: 1087-1096. 
Powell, B. N. et al. (1973) PLSC 4: 445-460.

Reid, A. M. et al. (1972) Meteoritics 7: 395-415.

Reid, A. M. et al. (1977) PLSC 8: 2321-2338.

Rhodes, J. M. et al. (1973) PLSC 4: 1127-1148.

Rhodes, J. M. et al. (1974) PLSC 5: 1097-1117.

Rhodes, J. M. et al. (1976) PLSC 7: 1467-1489.

Rhodes, J. M. et al. (1977) PLSC 8: 1305-1338.

Rose, H. J., Jr. et al. (1972) PLSC 3: 1215-1229.

Rose, H. J., Jr. et al. (1973) PLSC 4: 1149-1158.

Rose, H. J., Jr. et al. (1974) PLSC 5: 1119-1133.

Scoon, J. H. (1971) PLSC 2: 1259-1260.

Scoon, J. H. (1977) Lunar Sample Studies, NASA SP-418. Washington, D.C: 5.

Smales, A. A. et al. (1971) PLSC 2: 1253-1258.

Strasheim, A. et al. (1972) PLSC 3: 1337-1342.
Taylor, S. R. et al. (1972) PLSC 3: 1231-1249.

Taylor, S. R. et al. (1973) PLSC 4: 1445-1459.

Taylor, S. R. et al. (1977) Geophys. Res. Lett. 4: $207-210$.

Vaniman, D. T. and Papike, J. J. (1977) Geophys. Res. Lett. 4: 497-500.

Wakita, H. et al. (1971) PLSC 2: 1231-1236.

Ware, N. G. et al. (1977) pp. Lunar Sample Studies, NASA SP-418. Washington, D.C.: 49-59.

Warner, R. D. et al. (1977) PLSC 8: 2051-2066.

Wiik, H. B. (1975) Tähtiaika 5: 4-15.

Willis, J. P. et al. (1971) PLSC 2: 1123-1138.

Willis, J. P. et al. (1972) PLSC 3: 1269-1273.

Manuscript received, October 10, 1979 